DOI: 10.38136/jgon.768239

\title{
Az bilinen bir konu 'Menstrüel Psikoz': Bir olgu sunumu ve kısa bir gözden geçirme
}

\section{A little known topic 'Menstrual Psychosis' : A case report and a short review literature}

\section{Sabri ÇOLAK \\ Güner SUYABATMAZ \\ Çiçek HOCAOĞLU ${ }^{3}$}

(1) Orcid ID:0000-0002-4301-6104
(1) Orcid ID:0000-0001-6493-4265
(1) Orcid ID:0000-0001-6613-4317

${ }^{1}$ Recep Tayyip Erdogan University Faculty of Medicine, Department of Obstetrics and Gynecology, Rize, Turkey

${ }^{2}$ Avrasya University Faculty of Arts \& Sciences, Department of Psychology, Trabzon, Turkey

${ }^{3}$ Recep Tayyip Erdogan University Faculty of Medicine, Department of Psychiatry, Rize, Turkey

\section{öz}

Menstrüel psikoz (MP), adet döngüsü ile ilişkili ve önemli ruhsal değişikliklere neden olabilen bir durumdur. Tanı ve tedavi yaklaşımları hakkında bilgi sınırlıdır. Genellikle 16 yaşın altındaki genç kadınlarda meydana geldiği bildirilen MP, tipik olarak adet öncesi döngüye uygun, kısa süreli psikotik semptomlarla akut bir başlangıca ve menstrüasyon kanamasının kesilmesinden birkaç gün sonra sona eren klinik bir görünüme sahiptir. Psikotik semptomlara ek olarak, hastaların önemli duygudurum semptomları olabilir. Bu çalışmada psikiyatri polikliniğine insanlardan şüphe duyma, onlardan kötülük göreceğini düşünme, odaklanamama, dikkatte azalma, isteksizlik ve uykusuzluk şikayetleri ile başvuran 42 yaşında kadın hasta sunuldu. Hasta bu semptomların ergenlik yaşlarından itibaren hemen her adet öncesi döneminde meydana geldiğini bildirdi. Diğer çaışmalardan farklı olarak, olgumuz yetişkin yaştadır ve menarştan beri olan MP belirtileri için geç tanı almış olması dikkat çekicidir.

Anahtar Kelimeler: Menstrüel Psikoz, tanı, tedavi

\section{INTRODUCTION}

Changes in mental status associated with the menstrual cycle in women cause significant health problems. In particular, the premenstrual and menstrual phases of the menstrual cycle are periods in which sensitivity is increased in terms of exacerbation of symptoms contained in psychiatric disorders. It is reported that admission to a psychiatric clinic is concentrated in these phases in women (1). According to Brockington; In the 19th century, the relationship between psychosis and menstruation was first reported by Krafft-Ebing in 1896 (1). In some women, it was noted that a picture with psychotic symptoms appeared during or just before menstruation in which serum estrogen levels decreased, and this was called "menstrual psychosis" $(2,3)$. MP, which has been reported as case reports in the literature

\section{ABSTRACT}

Menstrual psychosis (MP) is a condition that is associated with the menstrual cycle and can cause significant mental changes. Information about diagnosis and treatment approaches is limited. MP, which is generally reported to occur in young women around the age of 16 , typically has an acute onset consistent with the premenstrual cycle, with short-term psychotic symptoms, and a clinical appearance that ends within a few days of discontinuation of menstruation bleeding. In addition to psychotic symptoms, patients may have significant mood symptoms. In this study, a 42-year-old female patient presented to the psychiatry outpatient clinic with complaints of suspicion of people, thinking that she would see them evil, inability to focus, attention, lack of willingness and insomnia. The patient reported that these symptoms occur in almost every premenstrual period starting from adolescence. Unlike other studies, our case is in adult age and it is noteworthy that she was late diagnosed for MP symptoms since menarche.

Key words: Menstrual psychosis, diagnosis, treatment

to date, is an uncommon condition with acute onset, short-term psychotic symptoms consistent with the menstrual cycle seen in unmarried young women, usually under 20 years of age, and features that terminate within a few days after discontinuation of menstrual bleeding (4). Symptoms in MP may occur concurrently with puberty or immediately after puberty (5). Information on the etiology, clinical presentation, and treatment approach of MP is limited $(3,6)$. There is a need for a better understanding of the etiology and clinical manifestations of MP in different age groups and treatment approaches that have not yet been included in the diagnostic classifications, but adversely affect the quality of life of women of reproductive age. Therefore, in this study, we aimed to contribute to the literature by presenting a female patient who presented with psychiatric symptoms especially during perimenstrual phase of the menstrual cycle. 


\section{CASE}

Ms. S, 42 years old, single, high school graduate, housewife, lives with her family. The patient applied to our psychiatry outpatient clinic voluntarily for the first time in September 2018. Ms S. stated that people around her talked about herself, had difficulty focusing her attention on something, found herself inadequate, worthless and forgetful. The patient added that she had difficulty falling asleep on some nights, crying for no reason, going to the grave of her father who had passed away recently, had suicidal thoughts and her complaints increased for the last 2 weeks. Ms. S stated that her first complaints started in adolescence as inward closure, alienation from people and obsessive thoughts. Therefore, she stated that she applied to many physicians and used different types of antipsychotics and antidepressant drugs and found partial benefit. Since she had suicidal ideation and plans after psychiatric evaluation, her relatives were contacted by telephone and informed that she needed inpatient treatment. However, the patient and her relatives refused inpatient treatment. The patient was diagnosed with major depressive disorder (showing psychotic features consistent with mood) according to DSM-5. Citalopram (20 mg/day) and aripiprazole ( $5 \mathrm{mg} /$ day) were started and 1 week later she was called for a follow-up visit with her relatives. After the first interview, Ms. S's mother, who came to the policlinic control with her daugther, was interviewed. Her mother said that the patient has been suspicious of people especially during her perimenstrual phase of the menstrual cycle, has moved away from them, has often had discusions with neighbors and relatives, has exhibited meaningless speech and behaviors, has been skeptical, irritable and angry, does not want to leave the house, and does not do housework. The patient has no history of physical illness, surgery or trauma. No neurological or psychiatric disease was defined in the family.

Vital signs were normal, neurological and other systemic examinations were normal. There were no pathological findings in the hemogram and biochemistry. The hormone tests were normal (thyroid function tests, parathormone, ceruloplasmin, vasculitis markers, vitamin b12, ferritin, folic acid were within normal limits). Gonadal hormone evaluation; FSH: $18 \mathrm{IU} / \mathrm{L} \mathrm{LH:} 5.99 \mathrm{IU}$ / L estradiol $12 \mathrm{pg} / \mathrm{mL}$ prolactin was measured at $5 \mathrm{ng} / \mathrm{mL}$. The patient was consulted by the Obstetrics and Gynecology Clinic. It was learned that the patient, who had been followed with citalopram $20 \mathrm{mg} /$ day and aripiprazole $20 \mathrm{mg} /$ day for the last 8 months, had no complaints during her menstrual periods. Before the case presentation, the patient was informed about the study and informed consent was obtained.

\section{DISCUSSION}

Although mental changes associated with the menstrual cycle have been known since the early years of history, there are still clinical manifestations that cannot be fully explained and that are not included in the diagnostic classifications. Few studies have been conducted to identify and investigate affect and behavioral changes associated with the menstrual cycle. On the other hand, systematic data on the etiology and treatment of premenstrual dysphoric disorder (PDD) reported to be related to the menstrual cycle have been increasing, yet there is still no consensus on the exact limits that distinguish the diagnosis of premenstrel dysphoric disorder from other mood disorders (2). However, in almost all studies related to the menstrual cycle, it is stated that the period before menstrual cycle is a risky period for many mental symptoms, the number of physician consultations increased during this period and not all mental changes related to menstrual cycle can be evaluated with the diagnosis of PDD (3). MP also differs from PDD with its clinical appearance with schizophrenia symptoms affecting women in reproductive age. Sudden onset, short duration of psychotic period and ending with full recovery, not speaking in psychotic period, delusions, hallucinations, and occurrence of psychotic period generally parallel to menstrual cycle are characteristic of MP. Typically, symptoms appear in the luteal phase of the menstrual cycle, a few days before menstruation, resolve within a short time, several days with bleeding, and recur during the next menstrual bleeding period. Initial symptoms are usually seen within a few years after menarche, similar to our case, and persist for many years if left untreated. In most of the cases, there is no family history of psychiatric disease as in our case $(4,5)$. Our case was diagnosed as MP because of the short-term psychotic period characteristics that started before each perimenstrual phase and completely recovered after the end of the menstrual cycle. It has been reported that PDD and chronic psychotic disorder worsening during mensturtion should be excluded in the differential diagnosis $(2,6)$. In our case, the diagnosis of exacerbated psychotic disorder during menstruation was excluded due to the absence of a diagnosis of mental disorder prior to the clinical symptoms associated with the premenstrual cycle. It has been reported that symptoms may change periodically in MP and may be confused with the diagnosis of PDD in the presence of mood features (4-7). The presence of depressive symptoms in our case was consistent with these findings. However, the presence of psychotic symptoms may differentiate this diagno- 
sis from PDD. In our case, the diagnosis of PDD was ruled out because of significant psychotic symptoms. Irritability, emotional volatility, depressive mood, crying, fear, hypersensitivity, anxiety and somatic complaints were reported in the cases (8). In our case, anxiety and mood symptoms were observed along with psychotic symptoms. It has been reported that in some cases with MP, symptoms of over-dependence or regression to family members may be observed $(8,9)$. In our case, fear, confusion, dependence on family members and regression symptoms were observed. Information on MP treatment is limited. To this day, a large number of drugs (antipsychotic agents, mood stabilizers, estrogen, androgen, progesterone, oral contraceptive agents, thyroid hormone, clomiphene, antidepressant agents, electroconvulsive therapy, benzodiazepines, bromocriptine, benzosidazole, gosadoline, gosadoline) were used (10). There are no treatment guidelines for MP and it has been reported that physicians can select antipsychotic, antidepressant and oral contraceptive drugs according to the case (11). Some authors have reported that standard antipsychotic drugs do not affect the frequency and course of MP. (11). However, there are also case reports of complete recovery with antipsychotic drugs (10). In our case, it was observed that MP symptoms improved after the addition of aripiprazole to antidepressant drug use. In studies with contradictory results on treatment efficacy, the ineffectiveness of low and high dose antipsychotic drugs led researchers to hormonal therapies. For this purpose, suppression of menstruation to prevent symptoms that started a few days before menstrual bleeding was considered and oral contraceptive drugs were used in the treatment (12). Especially in the treatment of contraceptives with more predominant estrogen ratios, it has been suggested that estrogen can reduce the monoamine oxidase activity and alter norepinephrine levels in the synapses, thus controlling the table (12). Danazol and steroid derivatives, which can suppress ovulation and menstruation, are other drug groups that have been used in treatment (10). Antidepressant drugs and electroconvulsive therapy are other treatment methods used in the treatment of MP (10). Citalopram was used in the treatment of our case.

As a result; mental state changes associated with the menstrual cycle cause significant health problems. Clinicians' sensitivity to the mental state changes associated with the menstrual cycle will improve the life quality of the patients. As in the case in our study, late diagnosis of MP or not being defined will negatively affect the patients' quality of life. The sensitivity of clinicians to mental state changes associated with the menstrual cycle will prevent the destructive consequences of MP. Future etiology and clinical presentation of MP should be elucidated with large-scale and interdisciplinary forward-looking studies.

\section{REFERENCES}

1.Reilly TJ, Sagnay de la Bastida VC, Joyce DW, Cullen AE, McGuire $P$. Exacerbation of psychosis during the perimenstrual phase of the menstrual cycle: Systematic review and meta-analysis. Schizophr Bull 2020; 46:78-90.

2. Brockington I. Menstrual psychosis: a bipolar disorder with a link to the hypothalamus. Curr Psychiatry Rep 2011;13:193-97.

3. Thippaiah SM, Nagaraja S, Birur B, Cohen AW. An interesting presentation about cyclical menstrual psychosis with an updated review of literature. Psychopharmacol Bull 2018; 48:16-21.

4. Fatica JP, Jiwani S, Salman R, Majeed S. Premenstrual psychosis in an adolescent: A case report. Clin Schizophr Relat Psychoses 2018; 26. doi: 10.3371/CSRP.FAJI.061518.

5. López Arteaga T, Loro López M. Cyclic psychosis and menstruation: presentation of a case. Rev Psiquiatr Salud Ment 2013:6:52-3

6. Aktepe E, Ozen E, Eroglu FO. Menstrual psychosis: a case report. Anadolu Psikiyatri Derg 2016; 17:88-90.

7. Sonmez I, Kosger F. Menstrual cycle in schizophrenic patients: Review with a case. Arch Neuropsychiatr 2015; 52:41719.

8. Santos-Cubina J, Castaing-Lespier PA, Sabate N, Torres-Martin A, Quinones-Fernandini VM. Menstrual psychosis: presenting symptom of bipolar disorder not otherwise specified in a 13-years-old Hispanic female. Bol Asoc Med PR 2013; 105:53-5.

9.Vengadavaradan A, Sathyanarayanan G, Kuppili PP, Bharadwaj B. Is menstrual Psychosis a Forgotten Entity?. Indian J Psychol Med 2018;40:574-76.

10.Thippaiah SM, Nagaraja S, Birur B, Cohen AW. An Interesting Presentation About Cyclical Menstrual Psychosis with an Updated Review of Literature. Psychopharmacol Bull 2018;48:16-21.

11.Che KI. Recurrent Psychotic Episodes with a Near-monthly Cycle. East Asian Arch Psychiatry 2016; 26 :137-140.

12.Otsuka K, Sakai A, Okudera T, Shibata E, Matoh K, Kawamura S. Oral contraceptive administration prevents relapse of periodic psychosis with hyper-prolactinemia. Psychiatry Clin Neurosci 2007; 61:127-28. 